\title{
PENDIDIKAN INKLUSI SEBAGAI IMPLEMENTASI NILAI-NILAI KARAKTER BANGSA
}

\author{
${ }^{1}$ Nurfatah dan ${ }^{2}$ Yasir Arafat \\ ${ }^{1}$ SD Negeri 8 Talang Kelapa Banyuasin \\ ${ }^{2}$ Universitas PGRI Palembang \\ e-mail: nurfatah72@gmail.com
}

\begin{abstract}
This study aimed at exploring the implementation of the nation's character values in relation to the implementation of inclusive education in SD Negeri 8 Talang Kelapa. Currently the moral crisis occured in various countries and also in Indonesia. It need to strengthen character education to overcome this problem. Education in Indonesia also aimed at shaping the human character of Indonesia to be well manifested with the behavior and attitude of living in accordance with the soul of Pancasila. This nation will progress if its education is able to change the character of the nation that is not good to the noble values of Pancasila. Inclusive education as an education that accommodates students with diverse backgrounds, including those with special needs, and learning together in one class. Inclusive education as an implementation of the nation's character values. This research was a qualitative research with case study. This research was conducted in SD Negeri 8 Talang Kelapa Banyuasin. The results showed that inclusion education is able to implement the character values among the prominent ones 1) social care 2) tolerance; 3) independent. Activities in the implementation of character values include learning, habituation, and extra curricular.
\end{abstract}

Keywords: Inclusive education, the Nation's Character Values, SD Negeri 8 Talang Kelapa

\section{PENDAHULUAN}

Dalam Undang-Undang Dasar Negara untuk memperoleh pendidikan yang bermutu. warga negara mempunyai hak yang sama

Di sisi lain data dari Dinas Pendidikan bahwa salah satu tujuan Negara Kesatauan Propinsi Sumatera Selatan tahun 2012 masih Republik Indonesia (NKRI) adalah ada 4,48\% yang belum sekolah dari jumlah mencerdasakan kehidupan bangsa, kemudian penduduk Sumatera Selatan usia 7-12 tahun dalam pasal 31 ayat (1) UUD 1945 berbunyi berarti 45.588 orang anak. Angka putus Setiap warga negara berhak mendapat sekolah 0,03\% atau 3,052 orang anak yang pendidikan, selanjutnya dalam Undang terpaksa putus sekolah, salah satu Nomor 20 tahun 2003 tentang Sistem penyebabnya adalah pembelajaran yang tidak Pendidikan Nasional Bab IV Pasal 4 Ayat (1) ramah anak, diskriminatif, sehingga anak Pendidikan diselenggarakan berdasarkan merasa tidak nyaman belajar di sekolah demokrasi dan berkeadilan dan tanpa (Disdik Sumsel, 2012). Di antaranya yang diskriminasi, pasal 5 dinyatakan bahwa setip tidak sekolah dikarenakan belum meratanya dan jauhnya jarak sekolah SLB yang ada di 
tingkat kabupaten/kota. Berdasarkan hasil karakter untuk mengatasi masalah bangsa ini, survei sosial ekonomi nasional Badan Pusat bangsa ini akan maju jika pendidikannya Statistik (BPS) pada tahun 2016 mampu merubah karakter anak bangsa yang menunjukkan bahwa, dari 4,6 juta anak yang tidak baik menuju nilai- nilai luhur pancasila tidak sekolah, satu juta di antaranya adalah yang kita junjung tinggi.

anak-anak berkebutuhan khusus /ABK Pendidikan di Indonesia juga (www.CNN.Indonesia, tanggal 29/08/2016). bertujuan membentuk karakter manusia Pemerintah telah menggagas sekolah inklusi Indonesia menjadi baik yang terwujud dengan dimana sesuai Peraturan Menteri Pendidikan perilaku dan sikap hidup sesuai dengan jiwa Nasional RI Nomor 70 Th 2009, Tentang pancasila. Karakter dapat diartikan sebagai Pendidikan Inklusif bagi Peserta Didik yang sesuatu yang mengualifikasi seorang pribadi. Memiliki Kelainan dan Memiliki Potensi Karakter menjadi identitas yang mengatasi Kecerdasan dan/atau bakat Istimewa. pengalaman kontingen yang selalu berubah.

Berdasarkan permen ini pendidikan Dari kematangan karakter inilah, kualitas inklusi dapat di jelaskan bahwa system seorang pribadi diukur (Jalaludin, 2012). penyelenggaraan pendidikan yang Pendidikan akan mencakup pengajaran dan memberikan kesempatan kepada semua pelaksanaan nilai-nilai. Isi pendidikan adalah peserta didik yang memiliki kelainan dan tindakan yang akan membawa peserta didik memiliki potensi kecerdasan dan/atau bakat mengalami dan menghayati nilai-nilai istimewa untuk mengikuti pendidikan atau kemanusiaan, menghargai, dan meyakini, pembelajaran dalam satu lingkungan sehingga peserta didik membangun nilai-nilai pendidikan secara bersama-sama dengan tersebut kedalam kepribadiannya.

peserta didik pada umumnya Saat ini krisis Pendidikan merupakan upaya moral di berbagai negara termasuk di negara membantu dan membimbing peserta didik kita, ditandai dengan meningkatnya pergaulan dalam mengembangkan dan memperkuat hati sek bebas, kekerasan remaja, tawuran antar nuraninya (Kristiawan, 2016:23). Menurut kelas/sekolah, kejahatan terhadap teman, pendapat Garbarino \& Brofenbrenner dalam penyalah gunaan obat terlarang, narkoba, (Zubaedi, 2012:7) bahwa jika suatu bangsa pornografi, pemerkosaan, perampasan ingin bertahan hidup maka bangsa ini harus menjadi masalah sosial yang belum bisa memiliki aturan yang menetapkan apa yang diatasi secara tuntas (Zubaedi, 2011: 2). salah dan apa yang benar, apa yang boleh dan Sehingga perlu penguatan pendidikan apa yang tidak boleh dilakukan, apa yang adil 
dan apa yang tidak adil, apa yang patut dan 2011:225) dari National Louis University, apa yang tidak patut, oleh karena itu perlu USA menyatakan bahwa karakter yang adanya etika dalam bicara, aturan dalam diajarkan di sekolah adalah kepanjangan dari berlalu lintas dan aturan sosial lainnya. karakter, moral atau nilai yang ada dan Pemerintah berupaya dalam hal ini dihargai dimasyarakat, seperti kejujuran, untuk mengembangkan kemampuan dan pantang menyerah, kebersahajaan, menjaga membentuk watak serta peradaban adalah emosi, di mana sekolah berperan sebagai dengan menggulirkan pendidikan karakter. agen moral. Revolusi mental harus dimulai Hal ini didasarkan bahwa pendidikan dari pendidikan, mengingat peran pendidikan merupakan pembentukan karakter (character sangat strategis dalam membentuk mental building). Bahkan, pendidikan karakter bisa anak bangsa. Pengembangan kebudayaan menjadi salah satu sarana pengkulturan dan maupun karakter bangsa diwujudkan melalui pemanusiaan, disebabkan peran pendidikan ranah pendidikan (Kristiawan, 2015:15). karakter bukan saja bersifat integratif, dalam Ahmad dkk (2017) mengungkapkan upaya arti mengukuhkan moral intelektual peserta peningkatan sumber daya manusia merupakan didik, melainkan juga bersifat kuratif, baik upaya yang terintegrasi dengan peningkatan secara personal maupun sosial, yakni bisa mutu pendidikan. Pendidikan sebagai sektor menjadi salah satu sarana penyembuh yang sangat vital dalam rangka membangun penyakit sosial (Koesoema,2010:6). Menurut sumber daya manusia yang bermutu, pendapat Lickona dalam Budiyanto (2014: memerlukan perhatian yang sangat besar dari 110) merujuk pada konsep good character semua pihak.

yang dikemukakan oleh Aristoteles SDN 8 Talang kelapa terletak di menegaskan bahwa karakter adalah "...the life Jl.Palembang-Betung KM 15 Kelurahan of right conduct - right conduct in relation to sukajadi, Kecamatan Talang kelapa other persons and in relation to one self". $\quad$ kabupaten Banyuasin. Dulu bernama SDN 2

Jadi Karakter adalah kehidupan Sukajadi dan merupakan SD terpadu yang dengan kondisi yang baik, baik yang menyelenggarakan pendidikan bagi anakberhubungan dengan orang lain dan anak berkebutuhan khusus. Dan mulai Tahun hubungan dengan diri sendiri. Konsep 2011 telah ditunjuk Dinas Pendidikan pendidikan karakter terus berkembang sejalan Kabupaten Banyuasin mejadi piloting sekolah dengan pemikiran-pemikiran baru, menurut inklusi bersama-sama 5 sekolah lain dan 84 pendapat Cunningham dalam (Suyanto, sekolah lain di Sumatera Selatan. Sejak saat 
itu mulai intensive dalam kegiatan inklusi badan PBB untuk Hak Azazi Manusia dari pelatihan guru, dan program-progam (UNHCR). Sejak itu hampir setiap tahun pendidikan inklusi lainya. Dalam hal ini SD deklarasi PBB tahun 1993 tentang Kesamaan inklusi menyelenggarakan pendidikan yang Kesempatan bagi penyandang Disabilitas, ramah anak dimana mengintegrasikan anak Pernyataan Salamanca tahun 1994 tentang berkebutuhan khusus dengan anak yang tidak Pendidikan Inklusi yang didukung 92 negara berkebutuhan khusus dalam kelas yang sama. dan 25 organisasi internasional. Pernyataan Pendidikan yang memenuhi kebutuhan anak Dakkar tahun 2000 tentang strategi dan target dan menghindari dari unsure-unsur kekerasan pendidikan inklusi. Sementara itu tahun 2005 dalam proses belajar mengajar.

tentang Pendidikan untuk semua, antara lain

\section{Pendidikan inklusi}

Setiap anak berhak mendapat pendidikan baik anak yang hambatan maupun anak yang memiliki kebutuhan khusus. Pendidikan khusus merupakan penyelenggaraan pendidikan untuk peserta didik yang berkelainan atau peserta didik yang memiliki kecerdasan luar biasa yang di selenggarakan secara inklusif atau berupa satuan pendidikan satuan pendidikan khusus pada tingkat pendidikan dasar dan menengah. Pelayananan pendidikan yang diberikan secara bersamaan, sehingga akan terjadi interaksi antara keduanya, saling memahami, mengerti adanya perbedaan, dan meningkatkan empati bagi anak-anak regular (ps.15 UU No 20 tahun 2003 tentang Sistem Pendidikan Nasional). Sejak tahun 1960 Majlis umum berkelainan dilayani di sekolah-sekolah mengadopsi Konvensi Anti Diskriminasi terdekat, di kelas reguler bersama-sama dalam Pendidikan yang dikeluarkan oleh teman seusianya. pendidikan dan pemeliharaan yang berkualitas didalam komunitas tempat tinggalnya sebagai bagian dari programprogram untuk perkembangan usia dini,prasekolah, pendidikan dasar dan menengah, terutama yang saat ini belum diberi kesempatan untuk memperoleh pendidikan di sekolah umum atau masih rentan terhadap marginalisasi dan eksklusif (Kemdikbud.2014). Menurut pendapat Staub dan Peck dalam (Sunaryo, 2009:6) bahwa pendidikan inklusi adalah penempatan anak berkelainan tingkat ringan, sedang, dan berat secara penuh di kelas regular, pendapat lain dari ahli Sapon-Shevin dalam (Sunaryo, 2009:6) yang menyatakan bahwa pendidikan inklusi adalah sistem layanan pendidikan yang mempersyaratkan agar semua anak dinyatakan bahwa semua anak memperoleh 
Pada tahun ajaran 2016/2017 Jumlah mengerti adanya perbedaan, dan siswa di SDN 8 Talang Kelapa berjumlah 634 meningkatkan empati bagi anak-anak reguler. siswa terbagi dalam 18 rombonga belajar, dan 2. Pendidikan karakter dari jumlah siswa tersebut ada 103 anak Pendidikan karakter menurut David berkebutuhan khusus terdiri dari 95 anak Elkind \& Freddy Sweet dalam (Zubaedi, lambat belajar; 5 anak kelainan fisik, 1 anak 2012: 15) pendidikan karakter adalah usaha tuna rungu, 1 anak tuna wicara, 1 anak autis sengaja (sadar) untuk memahami, peduli (sumber wawancara dengan kepala sekolah tentang dan melaksanakan nilai-nilai etika dan guru kelas tanggal 7 Oktober 2017). Visi inti. Menurut Perpres no 87 tahun 2017 sekolah SDN 8 Talang Kelapa mejadi sekolah tentang Penguatan Pendidikan Karakter yang Berkarakter, Berprestasi, Disiplin dan disingkat PPK adalah gerakan pendidikan di Inklusif, sedang misinya adalah ; 1) bawah tanggung jawab satuan pendidikan Menyiapkan generasi unggul yang memiliki untuk memperkuat karakter peserta didik Potensi dibidang IMTAQ dan IPTEK 2) melalui harmonisasi olah hati, olah rasa, olah Membentuk sumber daya manusia yang aktif, pikir, dan olah raga dengan pelibatan dan kreatif, inovatif sesuai dengan perkembangan kerja sama antara satuan pendidikan, zaman 3). Membangun citra sekolah sebagai keluarga, dan masyarakat sebagai bagiandari mitra terpercaya masyarakat 4) Gerakan Nasional Revolusi Mental (GNRM). Mengembangkan sekolah Inklusi ramah anak Salah satu tujuan dari PPK adalah untuk (wawancara dengan kepala sekolah Ibu membekali peserta didik sebagai generasi Idayanti,S.Pd tanggal 7 Oktober 2017). Setiap emas Indonesia tahun 2045 dengan jiwa individu pada dasarnya memiliki keunikannya Pancasila dan pendidikan karakter yang baik masing-masing. Berdasar pada prinsip guna menghadapi dinamika perubahan di tersebut maka kini dikembangkan sistem masa depan.Pendidikan karakter mempunyai pendidikan inklusi. Di dalam sekolah inklusi tiga fungsi; 1). pembentukan dan terdapat peserta didik dengan berbagai pengembangan potensi, 2).perbaikan dan macam latar belakang dari yang reguler penguatan bagi keluarga,satuan pendidikan, (biasa) sampai anak berkebutuhan khusus. masyarakat, pemerintah menuju bangsa yang Pelayananan pendidikan yang diberikan maju, mandiri, sejahtera, 3). penyaring secara bersamaan, sehingga akan terjadi budaya bangsa yang tidak sesuai (Zubaedi. interaksi antara keduanya, saling memahami, 2012:18). 
Nilai merupakan motor penggerak intelektualitas berupa kompetensi peserta sejarah, aktualisasi atasnya akan merupakan didik (Hendarman.dkk 2016:5).

sebuah pergulatan dinamis terus-menerus. Manusia, apapun kultur yang melingkupinya, tetap agen bagi perjalanan sejarahnya sendiri. Karena itu, loncatan sejarah masih bisa terjadi di negeri kita (Indonesia). Pendidikan karakter masih memiliki tempat bagi optimisme idealis pendidikan di negeri ini, terlebih karena bangsa kita kaya akan tradisi religius dan budaya (Jalaludin, 2012: 3). Dalam Undang-Undang Nomor 20 Tahun 2003 tentang Sistem Pendidikan Nasional telah ditegaskan bahwa Pendidikan nasional berfungsi mengembangkan kemampuan dan membentuk watak serta peradaban bangsa yang bermartabat dalam rangka mencerdaskan kehidupan bangsa, bertujuan untuk berkembangnya potensi peserta didik agar menjadi manusia yang beriman dan bertakwa kepada Tuhan Yang Maha Esa, berakhlak mulia, sehat, berilmu, cakap, kreatif, mandiri, dan menjadi warga negara yang demokratis serta bertanggung jawab. Selanjutnya, dalam Peraturan Pemerintah Nomor 19 Tahun 2005 tentang Standar Nasional juga terpapar secara tersurat berbagai kompetensi yang bersangkutan dengan karakter di samping intelektualitas. Hal tersebut menandakan bahwa sesungguhnya pendidikan bertugas mengembangkan karakter. sekaligus
Ada enam karakter utama (pilar karakter) pada diri manusia menurut Mu'in (2013:211) yang dapat digunakan untuk mengukur dan menilai watak dan perilakunya dalam hal-hal khusus. Keenam karakter ini dapat dikatakan sebagai pilar-pilar karakter manusia, di antaranya: respect (penghormatan), responsibility (tanggung jawab), citizenship-civic duty (kesadaran berwarga-negara), fairness (keadilan dan kejujuran), caring (kepedulian dan kemauan berbagi), trustworthiness (kepercayaan). Pendapat lain menurut Ki Hajar Dewantara filosofi pendidikan karakter terdiri dari olah hati (etika), olah pikir (literasi), olah raga (kinestetik), Olah karsa (estetika) sedang nilai-nilai karakternya menurut kemdikbud (2016:5) terdiri atas religius,jujur, toleransi, disiplin, kerja keras, kreatif, mandiri, demokratis, rasa ingin tahu, semangat kebangsaan, cinta tanah air, menghargai prestasi, bersahabat/ komunikatif, cinta damai, gemar membaca, peduli lingkungan. Dari nilai- nilai tersebut dikelompokkan menjadi kristalisasi nilai karakter menjadi; religius, nasionalis, integritas, mandiri, gotong royong, nilai nilai ini yang di kembangkan di sekolah dalam pendidikan karakter. 
Namun penerapan pendidikan pendidikan karakter dan pendidikan inklusif karakter tidak boleh sembarangan menurut perlu untuk di kaji.

Wibowo (2013:145) unsur yang berpengaruh terhadap penentuan karakter yaitu; 1). karakteristik peserta didik yang meliputi latar belakang, ekonomi, agama, budaya, serta tahap perkembangan; 2). konteks sekolah berada, meliputi seolah budaya masyarakat, dan falsafah negara, melbatkan berbagai komposisi nilai seperti nilai agama, moral, umum, dan kewarganegaraan. Sehingga pendidikan inklusi sebagai salah satu karakter sekolah bisa dikembangkan menjadi wahana implementasi nilai-nilai karakter bangsa.

Para ahli dalam bidang pendidikan semakin menyadari betapa pentingnya pendidikan karakter supaya tujuan pendidikan ini adalah kepala sekolah, guru-guru kelas, dapat tercapai, tujuan tersebut ialah peserta guru agama, tenaga kependidikan, wali murid didik mau dan mampu mengamalkan dan siswa di lingkungan SDN 8 Talang pengetahuan yang diperoleh dari dunia Kelapa. Pengumpulan data dilakukan dengan pendidikan dalam kehidupan sehari-hari. teknik observasi, wawancara, dan Menurut pendapat Coleman dalam (Zubaedi. dokumentasi. Data yang terkumpul kemudian 2012: 31) bahwa EQ (emotional quotient) dianalisis dengan menggunakan teknik menyumbang $80 \%$ terhadap keberhasilan analisis data interaktif yang terdiri dari tiga seseorang dalam kehidupan, di bandingkan kegiatan yang saling berinteraksi, yaitu dengan IQ (intelegence quotient) yang hanya reduksi data, penyajian data, dan penarikan menyumbang $20 \%$. Hal ini sangat sesuai kesimpulan atau verifikasi (Sugiyono,2007: dengan pola pendidikan inklusi semua anak 337).

berhak mendapatkan pendidikan dengan berbagai macam karakter dan kondisinya, sehingga bisa berkembang sesuai dengan potensi yang dimilikinya. Begitu pentingnya

\section{METODE PENELITIAN}

Penelitian ini merupakan penelitian kualitatif dengan studi kasus (case study) menurut Nazir (2009: 57) adalah peneltian tentang status subyek penelitian yang berkenaan dengan suatu fase suatu fase spesifik atau khas dari keseluruhan personalitas. Penelitian ini dilakukan di SDN 8 Talang kelapa yang merupakan salah satu sekolah penyelenggara pendidikan Inklusi di kabupaten Banyuasin dan telah melaksanakan pendidikan inklusi sejak tahun 2011 dan telah menjadi percontohan di kabupaten 
dengan sekolah-sekolah dasar lainnya, merupakan inti dari inklusi; (7) Kurikulum kekhasan itu di karenakan menerima anak yang fleksibel seyogyanya disesuaikan dengan berbagai karakter dan kebutuhan dengan anak, bukan kebalikannya. Dengan sehingga sekolah jug anak dengan berbagai menerapkan prinsip-prinsip diatas maka anak kondisi dan kebutuhannya dari yang lamb berkebutuhan khusus bisa belajar bersama Implementasi nilai-na menerapkan berbagai dan mendapatkan pelajaran sesuai dengan hal yang berbeda dengan sekolah lain kebutuhannya.

termasuk budaya sekolah dan implementasi Adapun nilai-nilai karakter yang nilai-nilai karakter melalui pendidikan inklusi diimplementasikan diantaranya; 1) peduli di SDN 8 Talang Kelapa kabupaten sosial, beragamnya siswa ada yang normal Banyuasin. dan ada berkebutuhan khusus menjadikan

Konsep dasar pelaksanaan pendidikan guru dan siswa peduli dengan sesama. Sudah inklusif mengacu pada dokumen internasional menjadi fitrah kalau manusia terdiri pernyataan Salamanca dan kerangka aksi bermacam-macam sifat dan bawaannya pada pendidikan kebutuhan khusus dalam misalnya; tinggi rendah, besar-kecil, hitamSunaryo (2009: 2) meliputi; (1) prinsip dasar putih, cepat-lambat, lahir normal-lahir dari sekolah inklusif adalah bahwa, selama berkebutuhan khusus. Disinilah kepedulian memungkinkan, semua anak seyogyanya sosial ditanamkam pada warga sekolah bahwa belajar bersama-sama, tanpa memandang semua mahluk adalah ciptaan Allah tidak ada kesulitan ataupun perbedaan yang mungkin yang sia-sia dan tidak berguna. pendidikan ada pada diri mereka; (2) anak yang inklusi kebutuhan anak akan terpenuhi sesuai menyandang kebutuhan pendidikan khusus dengan tingkat kebutuhannya. Kebutuhan seyogyanya menerima segala dukungan anak dapat berupa kebutuhan yang bersifat; tambahan yang mereka perlukan untuk (1) kebutuhan sementara merupakan menjamin efektifnya pendidikan mereka; (3) kebutuhan yang terjadi pada saat tertentu perbedaan itu normal adanya dan oleh yang dialami oleh seorang anak; (2) karenanya pembelajaran itu harus disesuaikan Kebutuhan permanen anak berkebutuhan dengan kebutuhan anak; (4) Sekolah perlu khusus berupa kebutuhan untuk hidup mengakomodasi semua anak; (5) Anak mandiri dan wajar selayaknya orang lain penyandang cacat seyogyanya bersekolah di dalam keluarga, sekolah, dan masyarakat; (3) lingkungan sekitar tempat tinggalnya; (6) Kebutuhan kultural berkaitan dengan pengajaran yang terpusat pada diri anak penerimaan kelompok terhadap anak di mana 
anak berada. Seoang anak perlu memperoleh bagi yang ada masalah pada mata di kemudahan untuk diterima sebagai anggota tempatkan bagian depan, bagi yang ada dalam lingkungan kelompoknya. Seorang masalah dengan pendengaran juga di letakkan anak luar biasa mengalami banyak hambatan dekat dengan meja guru dan satu bangku dalam menyesuaikan diri terhadap dengan anak normal agar bisa mendapat lingkungannya. Hal ini disebabkan bantuan seperlunya melalui tutor sebaya keberadaan dirinya yang mempunyai (wawancara kepala sekolah tanggal 12 keterbatasan beradaptasi dengan anggota- Oktober 2017).

anggota lain dilingkungannya. Di samping Menurut Purwanta (2002: 7) beberapa itu, masyarakat sendiri belum sepenuhnya manfaat yang didapat melalui pendidikan memahami kebutuhan anak luar biasa inklusi; (1) anak berkebutuhan khusus lebih sehingga mereka kadang-kadang bersikap mudah menyekolahkan anak di sekolah kurang menerima kehadiran anak luar biasa. terdekat di banding di SLB di kota kabupaten; keterbatasan fasilitas dan tidak fleksibelnya (2). menekan biaya, tenaga, waktu; (3) sistem pendidikan yang ada sekarang dan menghilangkan label sekolah khusus anak suasana lingkungan di sekolah tidak cacat; (4) anak berkebutuhan khusus terbiasa menjamin rasa aman bagi anal luar biasa berinteraksi dengan lingkungan masyarakat; dalam berintegrasi dengan lingkungannya (5) mementingkan pembauran bersama teman (Purwanta, 2002:4-5). Di sekolah SDN 8 sebaya. Hal inilah yang dirasakan masyarakat Talang kelapa terjalin interaksi sosial antara disekitar SDN 8 Talang kelapa yang selama anak berkebutuhan khusus dengan anak yang ini harus menyekolahkan di kota Palembang tidak berkebutuhan khusus, juga interaksi atau Pangkalan Balai di SLB, maka dengan warga sekolah guru, tenaga kependidikan, adanya sekolah inklusi di kecamatan Talang wali murid sehingga sudah maklum dan Kelapa menjadi lebih dekat untuk saling menghargai, dan membantu. Bahkan menyekolahkan anaknya yang berkebutuhan diceritakan oleh kepala sekolah ada anak khusus. terlihat adanya pembauran anak-anak kelainan fisik tidak bisa jalan yang di yang berkebutuhan khusus dengananak yang gendong 2 teman- temannyanya kemana dia normal mereka bermaian bersama, bercanda akan berjalan termasuk kekamar kecil atau tanpa canggung pada saat istirahat maupun sekedar bermain di halaman. Selain itu dalam saat pergi dan pulang sekolah. Guru selalu penempatan tempat duduk anak yang menekankan agar tidak mengejek anak yang berkebutuhan khusus mendapat perhatian berkebutuhan khusus bahkan membantunya, 
sekolah juga melarang adanya bullying masing-masing. Kurikulum yang di pakai (mengejek, menganggu, memeras dan lain- sama tapi disesuaikan dengan kondisi siswa lain) pada anak-anak yang berkebutuhan sebagai contoh anak yang tidak bisa bicara khusus hal ini terbukti dengan tidak akan diminta menceritakan kembali dicanangkannya sekolah ramah anak, tetapi diganti dengan dituliskan. Target termasuk di dalamnya guru juga harus pencapaian kompetensi juga berbeda atara bersikap ramah pada siswa dan tindakan yang anak normal dengan anak lambat belajar selalu ingin memberi bantuan pada orang lain sebagai contoh anak kelas 1 mengenal dan masyarakat yang membutuhkan bilangan sampai seratus, sedang anak lambat (Berdasarkan pengamatan penulis tanggal 6 belajar di target samapai dua puluh s/d 12 Oktober 2017 di SDN 8 Talang (wawancara dengan Ibu sugiarti,S.Pd guru Kelapa). kelas I tanggal 10 Oktober 2017).

Nilai karakter toleransi, siswa SDN 8 Mandiri, anak anak SDN 8 Talang Talang Kelapa tediri dari bermacam macam Kelapa dilatih mandiri untuk siswa baru agama yaitu Islam, Kristen, Budha, Kong hanya di antar orang tuanya selama 1 minggu hucu, dan bermacam etnis ; melayu, dan seterusnya di antar sampai depan pagar palembang, jawa, china, guru-guru selalu sekolah, mengerjakan tugas sendiri dirumah menekankan agar menghargai sikap dan tanpa bergantung dari bantuan orang tua, tindakan yang menghindari perbedaan agama, prinsipnya lebih baik karya sendiri dari pada suku, etnis, pendapat, sikap, dan tindakan karya orang lain, hal ini bertujuan untuk orang lain yang berbeda darinya. Keragaman menumbuhkan sikap sikap dan perilaku yang ini juga muncul pada saat pentas seni dan tidak mudah tergantung pada orang lain perpisahan siswa yang memiliki bakat menari dalam menyelesaikan tugas-tugas. Anak anak daerah ditampilkan di panggung sesuai berkebutuhan khuhus disamping belajar dengan daerah yang asal siswa juga tari kreasi secara akademik yaitu pelajaran juga belajar yang di latih oleh guru. Pada saat peringatan mengurus dirinya secara bertahap dan sesuai hari besar missal maulid nabi Muhammad dengan kemampuannya. Penelitian lain oleh Saw siswa yang beragama lain diperbolehkan Budiyanto dan Imam Machali (2014) belajar dirumah. Juga pada saat pelajaran menyimpulkan bentuk-bentuk pembentukan agama Islam siswa yang beragama lain di karakter mandiri dilakukan melalui proses perbolehkan tidak mengikuti pelajaran, dan pendidikan secara terus-menerus, saling nilainya diambil dari sekolah agamanya mengisi antara kegiatan tatap muka teoritik 
dengan praktik keseharian dalam lingkungan sebaya bagi kawannya yang mengalami kondusif-aplikatif. Di SDN 8 Talang Kelapa hambatan dalam belajar (wawancara dengan di samping di jelaskan secara verbal juga di Sutiana,S.Pd guru kelas VI A pada tanggal 9 praktekkan dalam pembelajaran, diluar jam Oktober 2017).

mengajar, serta ekstra kurikuler. Sebagai Agar nilai-nilai karakter bisa contoh dalam pelajaran PJOK siswa di buat terimplementasi dalam kehidupan sehari-hari jadwal pengambilan dan pengembalian alat- perlu menerapkan prinsip-prinsip alat olah raga seperti bola voli, net, cone, pengembangan penguatan pendidikan gawang, matras untuk senam. dalam pelajaran karakter menurut Hendarman dkk (2016:9): Agama siswa menyiapkan tempat praktek (1) nilai-nilai moral universal; (2) holistic; (3) sholat secara bergantian seperti karpet, tempat terintegrasi; (4) partisipatif; (5) kearifan air wudhu. Dalam ekstra kurikuler drumb lokal; (6) kecakapan abad 21; (7) adil dan band siswa membawa alat perlengkapan inklusif; (8) selaras dengan perkembangan drumb band ke lapangan secara mandiri dan peserta didik; dan (9) terukur. Pelaksanaan mengembalikan lagi setelah selesai latihan. pendidikan karakter di SDN 8 Talang Kelapa Dalam ektrakurikuler drum band siswa juga mengikuti prinsip-prinsip peguatan menyiapkan perlengkapan pramuka seperti pendidikan karakter, nilai nilai moral yang tongkat pramuka, tali,pasak. Anak dikembangkan adalah nilai- nilai dari empat berkebutuhan khusus bersama-sama anak lain karakter utama meliputi religius, nasionalis, bertanggung jawab menjaga kebersihan kelas integritas, dan mandiri. Kegiatan sesuai dengan kemampuannya, kalaupun pengembangan pendidikan karakter sejalan tidak bisa menyapu kelas setidaknya jangan dengan pendidikan inklusi melibatkan mengotorinya dan ikut menjaga kebersihan. koamite sekolah, masyarakat lingkungan

Di SDN 8 Talang Kelapa bercampur sekitar, dunia usah sehingga terjalin anak yang berkebutuhan khusus dengan anak kerjasama yang baik saling mendukung yang tidak berkebutuhan khusus (normal), (wawancara dengan Kepala sekolah tanggal mereka belajar bersama-sama tanpa adanya 10 Oktober 2017).

pemisahan, yang membedakan adalah target Pendidikan karakter akan berjalan pencapaian materi disesuakan dengan kondisi dengan baik apa bila dilaksanakan dengan dan kemampuan anak masing-masing, jadi strategi yang baik, menurut pendapat Zubaedi KKM nyapun berbeda, anak yang sudah (2012:114) strategi yang bisa di lakukan menguasai materi sering kali menjadi tutor yaitu; (1) menggunakan prinsip keteladanan 
dari semua pihak, baik orang tenaga kependidikan di SDN Talang Kelapa tua,guru,masyarakat, maupun pemimpinnya; berlaku adil tanpa membedakan perbedaan (2) menggunakan prinsip kontuinitas/rutinitas agama, ras,suku, bahkan kondisi siswa yang (pembiasaan dalam aspek kehidupan); (3) berkebutuhan khusus atau bukan. (wawancara menggunakan prinsip kesadaran untuk dengan kepala sekolah Idayanti,S.Pd ibu bertindak sesuai dengan nilai karakter yang tanggal 8 Oktober 2017).

diajarkan. Disamping itu pendidikan karakter Nilai nilai karakter karakter dapat dilakukan dengan cara utuh dan menyeluruh dilaksanakan dengan berbasis struktur dimana pendidikan karakter menjadi jiwa kurikulum yang sudah ada dan sudah dimiliki bagi setiap kegiatan yang ada di lingkungan oleh sekolah, yaitu pendidikan karakter lembaga pendidikan yang mana mengandung berbasis kelas, budaya sekolah, dan makna; (1) mengembangkan kualitas individu masyarakat/komunitas, Albertus dalam di dalamnya; (2) mendesain program sesuai Hendarman, (2015:15). (1) penguatan tanggung jawab individu; (3) membangun pendidikan karakter berbasis kelas; (2) lingkungan yang ramah dan nyaman bagi penguatan pendidikan karakter berbasis pertumbuhan individu (carring community) budaya sekolah; (3) penguatan pendidikan sesuai dengan tahap perkembangan karakter berbasis masyarakat. Di SDN 8 pertumbuhannya (Koesoema, 2012:69). SDN Talang Kelapa penguatan yang berbasis kelas 8 Talang kelapa mempunyai moto "Sekolah dilaksanakan dalam proses pembelajaran ramah anak" sehingga menjadi acuan bagi dimulai dari penyusunan RPP yang semua kegiatan dan lingkungan yang mengintegasikan dengan pendidikan karakter, mengutamakan kepentingan anak sehingga proses selama pembelajaran, hingga evaluasi anak merasa nyaman untuk belajar dan orang dari nilai-nilai karakter. Pelaksanaan tua juga nyaman menyekolahkan anaknya di pendidikan karakter yang berbasis budaya SDN 8 Talang Kelapa khususnya bagi anak- sekolah diantaranya, mengucapkan salam dan anak berkebutuhan khusus. Dalam hal ini mencium tangan apabila berjumpa dengan prinsip keteladanan juga sudah dilksanakan, guru, bedoa bersama sebelum dan selesai misalnya dalam hal jam masuk sekolah guru belajar, menyanyikan lagu Indonesia raya memberikan tauladan dalam kedisiplinan sebelum belajar dan lagu wajib sesudah pelajaran dimulai pukul 07.15-12.15, maka belajar, membaca buku (literasi) 15 menit sebelum pelajaran dimulai guru sudah berada sebelum pelajaran dimulai, dan anak yang di sekolah. Prinsip adil dan inklusif guru-dan terbaik menceritakan kembali bacaanya akan 
di tampilkan pada saat upacara bendera hari (wawancara dengan ibu Kurniasih, senin denga di saksikan seluruh peserta penanggung jawab ekstrakurikuler tanggal 9 upacara, membersihkan halaman dan kelas Oktober 2017).

sebelum belajar di mulai, memberikan Program penguatan pendidikan penghargaan kepada siswa yang menang karakter melalui dilakukan melaui salah satu dalam lomba pada saat upacara bendera kegiatan yaitu;1) pendidikan karakter berbasis (wawancara dengan kepala sekolah tanggal 9 kultur sekolah; 2) pendidikan karakter Oktober 2017) berbasis komunitas (Hendarman. 2016:3),

Kegiatan ekstrakurikuler di SDN 8 sedang di SDN 8 Talang Kelapa, budaya Talang kelapa untuk meningkatkan minat dan sekolah banyak di isi kegiatan seperti doa bakat siswa juga sarana dalam pengembangan bersama, mengucapakan salam ketika pendidikan karakter seperti; pramuka, drum bertemu guru dan teman, dan peringatan hariband, rebana, Baca Tulis Alqur'an (BTA), hari besar islam. Hanya saja belum ada guru bola voli setiap hari sabtu setelah istirahat pembimbing khusus yang bukan beragama pertama diadakan kegiataan ekstrakurikuler Islam, 2 orang guru agama adalah guru bagi kelas V dan VI di bimbing oleh guru dan Pendidikan Agama Islam.

pelatih yang mampu di bidang tersebut dan Implementasi nilai-nilai karakter yang menggembirakan bahwa anak-anak melalui pendidikan inklusi di SDN 8 Talang inklusi yang memili kelemahan dalam Kelapa tidak lepas dari peran serta kepala pelajaran akademik justru banyak memiliki sekolah dengan menjalankan fungsi minat di bidang seni, olah raga dan dan managerial menurut Blumberg dan Greenfield mereka sangat antusias mengikuti kegiatan dalam (Danim \& khairil, 2014:184) Sebagai ekstrakurikuler tersebut sehingga guru pemimpin pendidikan dilembaganya kepala disamping mengembangkan potensi siswa sekolah memiliki beberapa tugas dan fungsi juga memberikan materi pendidikan karakter yaitu 1.) perencanaan program; 2). pelaksana pada siswa. Beberapa lomba yang pernah rencana kerja; 3). pengawasan dan evaluasi; diikuti dan menjadi juara; (1) lomba gerak 4).Kepemimpinan sekolah; 5). Menurut jalan HUT RI tahun 2017 (2). Juara 3 O2SN Sujanto dalam Kristiawan (2016:7) kecamatan cabang renang tahun 2017; (3) kepemimpinan yaitu perilaku seorang juara I FLSN tingkat kecamatan Talang pemimpin untuk mengarahkan, kelapa dan mewakili di kabupaten Banyuasin mempengaruhi, dan menjelaskan kepada tahun 2017 dan masih banyak lagi bawahan, berinisiasi dan memelihara 
kekompakan kelompok, sikap konsisten agar di tiap kecamatan agar layanan pada anak setiap anggota dapat memberikan sumbangan ABK (Anak Berkebutuhan Khusus) bisa lebih secara efektif kepada organisasi demi mudah menikmati pendidikan yang menjadi tercapainya tujuan Sistem informasi sekolah. haknya. Dengan melaksanakan pendidikan Kepala sekolah SDN 8 Talang Kelapa dalam inklusi anak belajar mengargai perbedaan, menjalankan fungsi manajerialnya disamping mengasihi sesama manusia, bergotong telah merencakan juga mengadakan royong, kerja sama, yang itu semua pengawasan dan evaluasi terhadap merupakan nilai-nilai karakter.

pelaksanaan sekolah inklusi dan pendidikan karakter. Hal ini bertujuan agar menjamin pelaksanaannya berjalan dengan lancar. Koordinator kegiatan inklusi di serahkan kepada ibu Sutiana,SPd dan koordinator ekstrakurikuler diserahkan kepada ibu Kurniasih. Secara berkala dilaksanakan bimbingan dan pelatihan pelaksanaan inklusi dengan mengundang pemateri dari pusat sumber SLB Banyuasin.

Pendidikan

inklusi yang mengintegrasikan anak berkebutuhan khusus (ABK) dengan anak yang normal di sekolah umum seperti SDN 8 Talang kelapa dengan interaksi timbal balik secara ternyata bisa mengimplementasikan nilai-nilai karakter terutama karakter Hasil penelitian bahwa pendidikan inklusi mampu mengimplementasikan nilai-nilai karakter diantaranya yang menonjol adalah. 1) peduli sosial 2) toleransi; 3) mandiri. Kegiatan dalam implementasi nilai-nilai karakter antara lain; pembelajaran, pembiasaan ,dan ekstra kurikuler. Pendidikan inklusi perlu diperluas

\section{KESIMPULAN}

Implementasi nilai-nilai karakter melalui pendidikan inklusi SDN 8 Talang Kelapa meliputi karakter; 1) peduli sosial; 2) toleransi; 3) mandiri. Ketiga karakter tersebut yang dominan muncul di pelaksanaan pendidikan inklusi di SDN 8 Talang kelapa. Kegiatan pengembangan pendidikan karakter sejalan dengan pendidikan inklusi melibatkan komite sekolah, masyarakat lingkungan sekitar, dunia usaha sehingga terjalin kerjasama yang baik saling mendukung. Pendidikan karakter dilakukan dengan cara utuh dan menyeluruh dimana pendidikan karakter menjadi jiwa bagi setiap kegiatan yang ada di lingkungan lembaga pendidikan yang mana mengandung makna; (1) mengembangkan kualitas individu di dalamnya; (2) mendesain program sesuai tanggung jawab individu; (3) membangun lingkungan yang ramah dan nyaman bagi pertumbuhan individu (carring community) sesuai dengan tahap perkembangan pertumbuhannya. Kegiatan ekstrakurikuler di 
SDN 8 talang kelapa untuk meningkatkan Koesoema, Doni A. (2012). Pendidikan minat dan bakat siswa juga sarana dalam Karakter Utuh dan Menyeluruh. Yogyakarta: Kanisius.

pengembangan pendidikan karakter

\section{DAFTAR PUSTAKA}

Ahmad, S., Kristiawan, M., Tobari, T., \& Suhono, S. (2017). Desain Pembelajaran SMA Plus Negeri 2 Banyuasin III Berbasis Karakter Di Era Masyarakat Ekonomi ASEAN. Iqra (Educational Journal), 2(2), 403-432.

Aprilana, E. R., Kristiawan, M., \& Hafulyon, H. (2017). Kepemimpinan Kepala Madrasah Dalam Mewujudkan Pembelajaran Efektif di Madrasah Ibtidaiyah Rahmah El Yunusiyyah Diniyyah Puteri Padang Panjang. Elementary, 4(1).

Budiyanto, Mangun. Imam Machali (2014) Pembentukan Karakter Mandiri Melalui Pendidikan Agricultural di Pondok Pesantren Islamic Studies Aswaja Lintang Songo Piyungan Bantul Yogyakarta. Jurnal Pendidikan Karakter, Tahun IV, Nomor 2, Juni 2014.

Danim. Sudarwan.,dan Khairil. 2014. Profesi Kependidikan. Bandung: CV Alfabeta.

DisdikSumsel (2013). Buku Panduan Pendidikan Inklusif Ramah Anak Provinsi Sumatera Selatan.

Hendarman, dkk. (2016). Kajian dan Pedoman Penguatan Pendidikan Karakter. Jakarta: Kemdikbud.

https://www.cnnindonesia.com/nasional/2017 0829083026-20-237997/satu-juta-anakberkebutuhan-khusus-tak-bisa-sekolah, di akses tanggal 19 November 2017.

Jalaludin (2012). Membangun SDM Bangsa Melalui Pendidikan Karakter. Jurnal Penelitian Pendidikan Vol. 13 No. 2 .

Koesoema, Doni A. (2010). Pendidikan Karakter: Strategi Mendidik Anak Di Zaman Global. Jakarta: Grasindo.
Kristiawan, M. (2016). Filsafat Pendidikan.

Kristiawan, M. (2016). Telaah Revolusi Mental dan Pendidikan Karakter dalam Pembentukan Sumber Daya Manusia yang Pandai dan Berakhlak mulia. Ta'dib, 18(1), 13-25.

Mu'in, Fatchul. (2013). Pendidikan Karakter: Konstruksi Teoretik dan Praktik. Yogyakarta: Ar-Ruzz Media

Nazir, Moh, (2009). Metode Penelitian. Bogor: Ghalia Indonesia.

Purwanta, Edi. (2002). Pendidikan Inklusi. Makalah disampaikan dalam Temu Ilmiah PLB Tingkat Nasional Tahun 2002 di UPI tgl. 6-8 Agt.2002.

Sunaryo. (2009). Manajemen Pendidikan Inklusif. Makalah Seminar Nasional Jurusan PLB FIP UPI - Pebruari 2009.

Suyanto, Slamet. (2011). Hasil Implementasi Pendidikan Karakter di Amerika Serikat: Meta -analisis Study, Prosiding Seminar Nasional Penelitian, Pendidikan dan Penerapan MIPA, Fakultas MIPA, Universitas Negeri Yogyakarta, $14 \mathrm{Mei}$ 2011.

Sugiyono. (2007). Memahami Penelitian Kualitatif. Bandung: CV. ALFABETA.

Wibowo, Agus (2013). Manajemen Pendidikan Karakter di Sekolah (Konsep dan Praktik Implementasi). Yogyakarta: Pustaka Pelajar.

Zubaedi. (2011). Desain Pendidikan Karakter Konsepsi dan Aplikasinya dalam Lembaga Pendidikan. Jakarta: Kencana Prenada Media Group. 
JMKSP

Jurnal Manajemen, Kepemimpinan, dan Supervisi 